\title{
Hubungan Aliran Komunikasi Organisasi dan Gaya Komunikasi Kepemimpinan dengan Kinerja Karyawan PT Maybank Indonesia Cabang Medan
}

\author{
Vella Stephanie $^{1}$, Riris Loisa ${ }^{2 *}$ \\ ${ }^{1}$ Fakultas Ilmu Komunikasi Universitas Tarumanagara \\ Email: vella.915170052@stu.untar.ac.id \\ ${ }^{2}$ Fakultas Ilmu Komunikasi Universitas Tarumanagara* \\ Email: ririsl@fikom.untar.ac.id
}

Masuk tanggal : 15-12-2021, revisi tanggal :06-01-2022, diterima untuk diterbitkan tanggal : 16-01-2022

\begin{abstract}
This research aims to find out the relationship of organizational communication flow and leadership communication style to the performance of employees of Bank Maybank Medan Branch. This research uses quantitative research approach with survey method. The population in this study were all employees of Bank Maybank Medan Branch and the sample taken entirely from the population of Bank Maybank Medan Branch. The data used in this study were primary data collected using questionnaires. Based on hypothesis test 1 and hypothesis test 2 of pearson correlation test result which shows that organizational communication flow variable and leadership communication style affects the performance of employees of Maybank Bank Medan Branch and has significant positive value.
\end{abstract}

Keywords: communication organization, employee, leadership communication

\begin{abstract}
Abstrak
Penelitian ini untuk bertujuan mengetahui hubungan aliran komunikasi organisasi dan gaya komunikasi kepemimpinan terhadap kinerja karyawan Bank Maybank Cabang Medan. Penelitian menggunakan pendekatan penelitian kuantitatif dengan metode survei. Populasi dalam penelitian ini adalah seluruh karyawan Bank Maybank Cabang Medan dan sampel yang diambil keseluruhan dari populasi Bank Maybank Cabang Medan. Data yang digunakan dalam penelitian ini adalah data primer yang dikumpulkan menggunakan kuesioner. Berdasarkan uji hipotesis 1 dan uji hipotesis 2 dari hasil uji korelasi pearson yang menunjukkan bahwa variabel aliran komunikasi organisasi dan gaya komunikasi kepemimpinan memengaruhi kinerja karyawan Bank Maybank Cabang Medan dan memiliki nilai positif signifikan.
\end{abstract}

Kata Kunci: aliran komunikasi organisasi, gaya komunikasi kepemimpinan, kinerja karyawan

\section{Pendahuluan}

Di era globalisasi banyak perusahaan yang mulai berlomba-lomba mewujudkan untuk perusahaan yang baik dan berkualitas. Dengan adanya persaingan yang ketat ini perusahaan-perusahaan mulai membuat perubahan-perubahan yang terjadi dan harus beradaptasi dengan perubahan tersebut di lingkungan bisnis. Untuk dapat mencapai tujuan tersebut perusahaan mulai menjadikan karyawan dalam proses tersebut. Pada hal ini, karyawan menjadi peranan penting dalam menjalankan aktivitas dan mempertahankan kelansungan proses kerja dalam suatu perusahaan. Namun untuk menjalankan aktivitas dan mempertahankan kelangsungan proses kerja dibutuhkan 
komunikasi yang baik dan efektif. Karena dengan komunikasi yang baik dapat mengkoordinasikan kegiatan, mengurangi beban manajerial serta meningkatkan kinerja.

Dalam suatu organisasi terdapat pimpinan dan bawahan (karyawan), untuk memperoleh kerja sama yang baik antara pimpinan dan karyawan, maka perlu suatu koordinasi yang didapatkan melalui komunikasi. Gaya komunikasi kepemimpinan dapat memengaruhi efektivitas komunikasi dari organisasi. Maka dari itu, dengan adanya gaya komunikasi kepemimpinan yang efektif akan menghasilkan kinerja yang baik dan bagus (Yuwarti dan Virgiawan, 2013).

Kinerja karyawan sendiri merupakan hasil kerja karyawan dalam melaksanakan tugas sesuai dengan tanggung jawab yang dilihat dari aspek kualitas, kuantitas, waktu kerja dan kerjasama untuk mencapai tujuan perusahaan (Siagian dan Khair, 2018). Public Relation memiliki peran penting dalam meningkatkan kinerja karyawan agar tercapai kinerja yang optimal. Public Relation merupakan suatu proses komunikasi yang terencana dalam rangka membangun hubungan antara perusahaan dengan publik atau masyarakat. Bank Maybank adalah suatu jaringan perbankan dan grup jasa keuangan yang memiliki peringkat kedua dalam bank terbesar di Malaysia, dan beroperasi sebagai jaringan perbankan penting di Singapura, Indonesia dan Filipina. Maybank Indonesia menyediakan berbagai produk dan jasa komprehensif melalui layanan perbankan ritel dan non-ritel, perbankan global serta pembiayaan otomotif melalui WOM Finance.

\section{Metode Penelitian}

Pendekatan penelitian ini menggunakan pendekatan penelitian kuantitatif. Pada hal ini digunakan metode survei dalam penilitian ini. Populasi diambil yang digunakan dengan seluruh karyawan Bank Maybank Cabang Medan, dan sampel diambil adalah seluruh populasi. Variabel operasional menentuan diperlukan untuk melihat jenis, indikator, serta skala dari variabel-variabel yang terkait dalam penelitian. Variabel-variabel terdapat dalam penelitian ini adalah variabel independen (variabel bebas) dan variabel dependen (variabel terikat). Variabel Y menjadi variabel dependen yaitu kinerja karyawan. Variabel X menjadi variabel dependen yaitu aliran komunikasi organisasi (X1) dan gaya komunikasi kepemimpinan (X2).

Pengumpulan data digunakan data primer dengan yang mengumpulkan menggunakan kuesiioner. Normal atau tidak normal populasi diambil yang berdistribusi melakukan uji normalitas. Dasar pengambilan kepustusan untuk menentukan kenormalan data dapat diukur dengan melihat angka probabilitasnya (Asyntotic Significance). Setelah dari itu menggunakan uji korelasi Pearson Product Moment mengetahui hubungan arah antara variabel dependen dan variabel independent.

\section{Hasil Temuan dan Diskusi}

Jenis kelamin berdasarkan responden yang ada dengan terdapat 27 responden jenis kelamin perempuan presentasi dengan 54,0\%, sedangakan responden jenis kelamin laki-laki 23 responden persentase 46,0\%. Karakteristik berdasarkan penggambaran usia, dilihat dapat responden kebayakan berusia 21-25 tahun memiliki 26 orang atau 52,0\%, sedangkan responden paling sedikit berusia $\geq 31$ tahun dengan banyak 2 orang. Penggambaran kareakteristik berdasarkan masa kerja, mayoritas 
responden dengan masa kerja satu tahun yaitu 22 orang atau 44,0\%, sedangkan responden sangat sedikit pada masa kerja empat tahun yaitu 6 orang atau 12,0\%.

Berdasarkan penggambaran karakteristik jabatan, diketahui bahwa kebanyakan responden dengan jabatan sebagai Customer Service yaitu sebanyak 13 orang atau 26,0\%, sedangkan paling sedikit responden dengan jabatan Kepala Teller dan Management Development yaitu sebanyak 3 orang atau 6,0\%. Berdasarkan penggambaran karakteristik status pribadi, kebanyakan responden dengan status pribadi belum menikah yaitu sebanyak 37 orang atau $74,0 \%$, sedangkan paling sedikit responden dengan status pribadi sudah menikah yaitu sebanyak 13 orang atau $26,0 \%$.

\section{Model Pengukuran}

Pembuatan kuisioner dilakukan dengan melakukan uji validitas terlebih dahulu. Valid atau tidak valid kuesioner dikertahui dalam uji validitas. Suatu kuisioner dinyatakan valid atau tidaknya dari pengujian tiap butir pertanyaan yang dilakukan dengan mencari skor korelasi dan skor item pertanyaan dengan skor total menggunakan teknik korelasi pearson product moment. butir suatu pertanyaan dinyatakan valid jika memiliki nilai $r$ hitung lebih besa $r$ table pada taraf signifikansi. Dengan jumlah uji coba kuesioner sebanyak 30 responden, maka dilakukan analisi korelasi antara skor item pertanyaan dengan skor total menghasilkan nilai $r$ table sebesar 0,361 .

Tabel 1. Hasil Uji Validitas

\begin{tabular}{|c|c|c|c|c|}
\hline Variabel & Item & r hitung & $r$ tabel & Keterangan \\
\hline \multirow{10}{*}{$\begin{array}{l}\text { Aliran } \\
\text { Komunikasi } \\
\text { Organisasi }\end{array}$} & UC1 & 0,835 & 0,361 & Valid \\
\hline & $\mathrm{UC} 2$ & 0,699 & 0,361 & Valid \\
\hline & DC1 & 0,628 & 0,361 & Valid \\
\hline & DC2 & 0,610 & 0,361 & Valid \\
\hline & DC3 & 0,519 & 0,361 & Valid \\
\hline & DC4 & 0,281 & 0,361 & Tidak Valid \\
\hline & DC5 & 0,570 & 0,361 & Valid \\
\hline & $\mathrm{HC} 1$ & 0,621 & 0,361 & Valid \\
\hline & $\mathrm{HC} 2$ & 0,762 & 0,361 & Valid \\
\hline & $\mathrm{HC} 3$ & 0,309 & 0,361 & Tidak Valid \\
\hline \multirow{14}{*}{$\begin{array}{l}\text { Gaya } \\
\text { Komunikasi } \\
\text { Kepemimpinan }\end{array}$} & OR1 & 0,721 & 0,361 & Valid \\
\hline & KO1 & 0,663 & 0,361 & Valid \\
\hline & $\mathrm{KO} 2$ & 0,807 & 0,361 & Valid \\
\hline & TG1 & 0,709 & 0,361 & Valid \\
\hline & KB1 & 0,647 & 0,361 & Valid \\
\hline & KT1 & 0,345 & 0,361 & Tidak Valid \\
\hline & TR1 & 0,727 & 0,361 & Valid \\
\hline & PR1 & 0,663 & 0,361 & Valid \\
\hline & DM1 & 0,617 & 0,361 & Valid \\
\hline & DM2 & 0,748 & 0,361 & Valid \\
\hline & KL1 & 0,813 & 0,361 & Valid \\
\hline & KL2 & 0,901 & 0,361 & Valid \\
\hline & KN1 & 0,598 & 0,361 & Valid \\
\hline & KW1 & 0,620 & 0,361 & Valid \\
\hline
\end{tabular}




\begin{tabular}{lcccc}
\hline Kinerja & KW2 & 0,212 & 0,361 & Tidak Valid \\
\cline { 2 - 5 } Karyawan & EF1 & 0,677 & 0,361 & Valid \\
\cline { 2 - 5 } & EF2 & 0,743 & 0,361 & Valid \\
\cline { 2 - 5 } & KM1 & 0,325 & 0,361 & Tidak Valid \\
\cline { 2 - 5 } & KM2 & 0,901 & 0,361 & Valid \\
\hline
\end{tabular}

Sumber: Olahan Data Peneliti

Tabel 2. Hasil Uji Reliabilitas

\begin{tabular}{lccc}
\hline \multicolumn{1}{c}{ Variabel } & $\begin{array}{c}\text { Cronbach's } \\
\text { Alpha }\end{array}$ & $\begin{array}{c}\text { Nilai } \\
\text { Kritis }\end{array}$ & Keterangan \\
\hline $\begin{array}{l}\text { Aliran } \\
\text { Komunikasi }\end{array}$ & 0,776 & 0,70 & Reliabel \\
$\begin{array}{l}\text { Organisasi } \\
\begin{array}{l}\text { Gaya Komunikasi } \\
\text { Kepemimpinan }\end{array}\end{array}$ & 0,860 & 0,70 & Reliabel \\
\hline Kinerja Karyawan & 0,860 & 0,70 & Reliabel \\
\hline
\end{tabular}

Sumber: Olahan Data Peneliti

Uji reliabilitas digunakan yang pada penelitian mengukur untuk ketepatan atau kehandalan suatu kuesioner merupakan yang indikator dari variabel. Suatu kuesioner ditentukan reliabel atau tidak dari ketetapan atau kestabilan jawaban respoden pertanyaan terhadap yang diberikan dari waktu ke waktu. Pengujian reliabilitas menghitung dengan besarnya nilai Cronbach's Alpha dari masing-masing variable yang diuji. Suatu kuisioner dinyatakan reliabel jika memiliki nilai Cronbach's Alpha lebih besar dari 0,70 .

Tabel 3. Hasil Uji Normalitas

\begin{tabular}{lcccc}
\hline \multicolumn{1}{c}{ Variabel } & Statistik & df & Sig. & Keterangan \\
\hline $\begin{array}{l}\text { Aliran Komunikasi } \\
\text { Organisasi }\end{array}$ & 0,108 & 50 & 0,200 & Normal \\
\hline $\begin{array}{l}\text { Gaya Komunikasi } \\
\text { Kepemimpinan }\end{array}$ & 0,109 & 50 & 0,191 & Normal \\
\hline Kinerja Karyawan & 0,117 & 50 & 0,085 & Normal \\
\hline
\end{tabular}

Sumber: Olahan Data Peneliti

Penyebaran data dilakukan dengan melakukan uji normalitas yang digunakan untuk menguji data tersebut normal atau tidak normal. Suatu data dapat dikatakan normal apabila data tersebut memiliki nilai signifikan lebih besar dari tingkat signifikan $\alpha=5 \%$ atau ( $p$ lebih kecil 0,05 ) dan jika data memiliki nilai sig lebih kecil dari tingkat signifikan $\alpha=5 \%$ atau ( $p$ lebih kecil 0,05) maka data tersebut dapat dikatakan tidak normal. Pada penelitian ini digunakan Teknik Kolmogrov-Smirnov dengan jumlah sampel sebanyak 50 responden. 
Vella Stephanie, Riris Loisa: Hubungan Aliran Komunikasi Organisasi dan Gaya Komunikasi Kepemimpinan dengan Kinerja Karyawan PT Maybank Indonesia Cabang Medan

Tabel 4. Hasil Uji Korelasi Pearson Product Moment

\begin{tabular}{lccc}
\hline \multicolumn{1}{c}{ Variabel } & r & Sig. & Keterangan \\
\hline $\begin{array}{l}\text { Aliran Komunikasi } \\
\text { Organisasi*Kinerja }\end{array}$ & 0,709 & 0,000 & $\begin{array}{l}\text { Positif dan } \\
\text { Signifikan }\end{array}$ \\
$\begin{array}{l}\text { Karyawan } \\
\text { Gaya Komunikasi } \\
\text { Kepemimpinan*Kinerja }\end{array}$ & 0,691 & 0,000 & $\begin{array}{l}\text { Positif dan } \\
\text { Karyawan }\end{array}$ \\
\hline
\end{tabular}

Sumber: Olahan Data Peneliti

Dalam mengetahui korelasi atau hubungan antar variabel yang diukur yaitu varibel aliran komunikasi organisasi dan gaya komunikasi kepemimpinan dengan variabel kinerja karyawan digunakan uji korelasi pearson product moment. suatu variabel memiliki hubungan yang kuat jika nilai $r$ lebih besar dari 0,6 serta bernilai positif dan memiliki nilai signifikan lebih kecil dari tingkat signifikan $\alpha=5 \%$ atau ( $p$ lebih kecil 0,05).

\section{Diskusi}

Uji hipotesa satu hasil bahwa hubungan variabel aliran komunikasi organisasi terhadap kinerja karyawan diuji yang dengan korelasi pearson nilai $r$ memiliki sebesar 0,709 dan sig nilai sebesar 0,000. Maka dari itu r nilai yang positif nilai sebesar 0,709 dan sig nilai lebih kecil dari tingkat signifikan $\alpha=5 \%$ atau $(0,000$ kecil 0,05$)$. Berarti bahwa yang pada variabel aliran komunikasi organisasi memiliki hubungan positif signifikan yang terhadap kinerja karyawan. Hasil tersebut bahwa dinyatakan aliran komunikasi organisasi memiliki hubungan yang signifikan terhadap kinerja karyawan Bank Maybank Cabang Medan. Dari hasil tersebut dinyatakan bahwa aliran komunikasi organisasi memiliki hubungan positif yang signifikan terhadap kinerja karyawan Bank Maybank Cabang Medan.

Hal tersebut dilihat di Bank Maybank Cabang Medan, dimana perusahaan ini menjunjung tinggi nilai-nilai perusahaan dalam bekerja secara tim dengan didasari saling menghargai dan menghormati serta berkomitmen memberikan kinerja dan pelayanan yang baik. Dengan demikian, karyawan Bank Maybank Cabang Medan akan merasa nyaman berada di lingkungan dengan tempat kerjanya. Ketika seorang karyawan memiliki perasaan tersebut, karyawan akan memberikan kinerja yang terbaik kepada perusahaan. Dengan demikian, semakin baik aliran komunikasi organisasi yang ada didalam suatu perusahaan, maka akan semakin meningkatkan kinerja karyawan.

Uji hipotesa dua hasil bahwa hubungan variabel gaya komunikasi kepemimpinan terhadap kinerja karyawan memiliki $\mathrm{r}$ nilai hasil dari uji korelasi pearson sebesar 0,691 dan sig nilai sebesar 0,000. R nilai positif sebesar 0,691 dan sig nilai lebih kecil dari tingkat signifikan $\alpha=5 \%$ atau $(0,000$ lebih kecil 0,05$)$, berarti yang terdapat positif hubungan signifikan pada variabel gaya komunikasi kepemimpinan. Hasil dari $\mathrm{H} 2$ disimpulkan dapat bahwa gaya komunikasi kepemimpinan memengaruhi kinerja karyawan Bank Maybank Cabang Medan.

Gaya komunikasi kepemimpinan merupakan suatu cara yang dilakukan oleh seorang pemimpin akan memengaruhi karyawan dalam hal berkerja sama. Ini juga merupakan upaya untuk memberikan semangat dalam mencapai tujuan yang telah ditetapkan. 
Keberhasilan suatu perusahaan baik secara keseluruhan maupun berbagai kelompok bergantung pada keefektif komunikasi pemimpin dalam perusahaan tersebut sehingga gaya komunikasi kepemimpinan berperan penting dan memiliki pengaruh besar dalam menentukan keberhasilan suatu perusahaan dalam mencapai tujuan. Keberhasilan suatu perusahaan mencapai tujuan perusahaan juga terlihat dari kinerja para karyawannya menyelesaikan dalam tugas atau pekerjaannya dan semangat dalam menyelesaikan setiap tugas atau pekerjaannya. Dengan demikian, semakin baik gaya komunikasi kepemimpinan yang ada di dalam suatu perusahaan, akan semakin meningkat pula kinerja karyawan.

\section{Simpulan}

Berdasarkan hasil analisis, dapat ditarik kesimpulan sebagai berikut: (1) Aliran komunikasi organisasi memiliki hubungan positif dengan kinerja karyawan Bank Maybank Cabang Medan; (2) Gaya komunikasi kepemimpinan memiliki hubungan positif dengan kinerja karyawan Bank Maybank Cabang Medan.

\section{Ucapan Terima Kasih}

Peneliti ingin mengucapkan terima kasih kepada Fakultas Ilmu Komunikasi Universitas Tarumanagara, narasumber, serta semua pihak yang turut membantu peneliti sehingga penelitian ini dapat diselesaikan.

\section{Daftar Pustaka}

Siagian, T. S., \& Khair, H. (2018). Pengaruh gaya kepemimpinan dan lingkungan kerja terhadap kinerja karyawan dengan kepuasan kerja sebagai variabel intervening. Maneggio: Jurnal Ilmiah Magister Manajemen. 1(1). 59-70.

Yuwarti, H., \& Virgiawan, P. Y. (2013). Hubungan gaya komunikasi pimpinan dan pegawai dengan kinerja pegawai. Wacana. 12(2). 111-123. 